\title{
Erratum: Ilyas and Athwal (2021). De-Radicalisation and Humanitarianism in Indonesia. Social Sciences 10: 87
}

\author{
Mohammed Ilyas ${ }^{1, *}$ and Rayvinder Athwal ${ }^{2}$ \\ 1 Department of Sociology, Social Policy and Criminology, University of Liverpool, Liverpool L69 3BX, UK \\ 2 School of Information Technology, Deakin University, Melbourne 3125, Australia; rayv@deakin.edu.au \\ * Correspondence: m.ilyas@liverpool.ac.uk
}

check for

updates

Citation: Ilyas, Mohammed, and Rayvinder Athwal. 2021. Erratum: Ilyas and Athwal (2021). De-Radicalisation and Humanitarianism in Indonesia. Social Sciences 10: 87. Social Sciences 10: 198. https://doi.org/10.3390/ socsci10060198

Received: 17 May 2021

Accepted: 21 May 2021

Published: 27 May 2021

Publisher's Note: MDPI stays neutral with regard to jurisdictional claims in published maps and institutional affiliations.

The authors wish to make the following correction to their paper (Ilyas and Athwal 2021). The second author of this paper is Rayvinder Athwal. The authors would like to apologize for any inconvenience caused. The change does not affect the scientific results. The manuscript will be updated and the original will remain online on the article webpage.

Author Contributions: Conceptualization, M.I. and R.A.; methodology, M.I. and R.A.; investigation, M.I. and R.A.; resources, M.I. and R.A.; writing-original draft preparation, M.I. and R.A.; writingreview and editing, M.I. All authors have read and agreed to the published version of the manuscript.

\section{Reference}

Ilyas, Mohammed, and Rayvinder Athwal. 2021. De-Radicalisation and Humanitarianism in Indonesia. Social Sciences 10: 87. [CrossRef] 